\title{
Author Correction: Complete genome sequence and transcriptomics analyses reveal pigment biosynthesis and regulatory mechanisms in an industrial strain, Monascus purpureusYY-1
}

Yue Yang, Bin Liu, Xinjun Du, Ping Li, Bin Liang, Xiaozhen Cheng, Liangcheng Du, Di Huang, Lei Wang \& Shuo Wang

Correction to: Scientific Reports https://doi.org/10.1038/srep08331, published online 09 February 2015

This Article contains errors.

The sequencing data underlying the study had been previously deposited on the institutional server. The authors have now additionally deposited it in GenBank, under accession code QDGY00000000. The Data Availability section should therefore read:

Data Availability

The genome sequence data and RNA-seq data generated in this project are available at http://spxy.tust.edu.cn/ duxj/index.html and in GenBank under accession code QDGY00000000.

(c) Open Access This article is licensed under a Creative Commons Attribution 4.0 International c. License, which permits use, sharing, adaptation, distribution and reproduction in any medium or format, as long as you give appropriate credit to the original author(s) and the source, provide a link to the Creative Commons license, and indicate if changes were made. The images or other third party material in this article are included in the article's Creative Commons license, unless indicated otherwise in a credit line to the material. If material is not included in the article's Creative Commons license and your intended use is not permitted by statutory regulation or exceeds the permitted use, you will need to obtain permission directly from the copyright holder. To view a copy of this license, visit http://creativecommons.org/licenses/by/4.0/.

(C) The Author(s) 2020 